Arab Univ. J. Agric. Sci., Ain Shams Univ., Cairo, 13(2), 453 - 458, 2005

\title{
THE INFLUENCE OF STEM CUTTING LENGTH AND IBA TREATMENTS ON PROPAGATION OF NATIVE SAUDI ARABIAN GRAPEVINE
}

[28]

\author{
Hamooh $^{1}$, B.T.
}

\begin{abstract}
The Saudi Arabian Ministry of Agriculture experimental station at Al-Maddina Al-Monwarah region, identified very few plantations of the most productive Vitis vinifera var. maddini with the highest fruit quality. This research was designed to optimize rooting effeciency in relation to cutting length and auxin treatment. Cutting length (long vs short) showed strong impact on rooting ability. Results showed that longer cuttings produce more and longer roots than shorter ones. IBA treatments up to the $500 \mathrm{ppm}$ level showed significant increase in root number, but do not have significant impact on root length. Rooted cuttings were planted in an open field for further evaluations. These findings may facilitate the clonal propagation of this valuable vines at Al-Maddina Al-Monwarah region, grapevine growers and Horticulturists in Saudi Arabia .
\end{abstract}

Key words: Propagation, Grapevine, Cuttings, Growth regulators

\section{INTRODUCTION}

Table grapevine (Vitis vinifera L.) is the second largest fruit production in Saudi Arabia after date palm. "Maddini" grapevine variety has been known for hundreds of years as one of the most commercially important fruit in Saudi Arabia. In the last few years, the Saudi Ministry of Agriculture experimental station at Al-Maddina Al-Monwarah region identified very few plantations of the most productive "Maddini" grapevine with the highest fruit quality (unpublished data). Almost no attempt or references were found in regard to mass propagation of this commercially important vines. Massive of literatures are found in grapevine vegetative propagation (Ezzili \& Bejaoui, 2001; Thomas \& Schiefelbein, 2001; Patil et al 2000; Cristoferi et al 1988; Harmail et al 1986 and Tewari, 1986). Auxins such as IAA, IBA \& NAA have been traditionally applied to improve rooting of grapevine stem cuttings (Geny et al 1998; Zhang et al 1997; Preece, 1987; Tewari, 1986 and Shatat, 1986). Branch order, length and diameter can have strong effect on grapevine rooting (Jiang et al 2000; Castro et al 1994;

1- Department of Arid Land Agriculture, Faculty of Meteorology, Environment and Arid Land Agriculture, King Abdulaziz University, Jeddah, Saudi Arabia 
Cristoferi et al 1988; Harmail et al 1986; Ehrlinger \& Howell, 1981 and Iacob \& Popescu, 1977). Effects of media or soil mixture were heavily researched to improving grapevine rooting (Song et al 2001 and Kawecki \& Kozlowski, 1995). The objective of this research was to: study the impact of two cutting length (short vs. long) in combination with different concentrations of (IBA) on adventitious root formation of "Maddini" grapevine.

\section{MATERIAL AND METHODS}

Healthy looking "Maddini" grapevine plants were selected as a source of cuttings. Cuttings were prepared three days before the actual treatments and transported to King Abdulaziz University experimental station at Hada Al-Sham. The present work was conducted on late winter of 2003/2004 at King Abdulaziz University experimental station greenhouses where controlled temperature, lighting and humidity to insure maximum root initiation and development. The study was set up in a $(2 \times 4)$ factorial experiment arranged in randomized complete block design (RCBD) with three replicates. Treatments consisted of control and three concentrations of (IBA) $(300,500$ and $1000 \mathrm{ppm}$ ) applied to longer (4-5 nodes) or shorter (1-2 nodes) hardwood stem cuttings. Thirty cuttings were assigned to each replicate. Quick dip method (for 1 min.) was used to perform the auxin treatment followed by planting the treated cuttings in rooting media (1 sand: 1 perlite: 2 peat moss). For each cutting, number of roots and root length were recorded. Rooted cuttings were then planted in an open orchard at King Abdulaziz University experimental station for further evaluation. Analysis of variance technique (ANOVA) was used to determine the significance of mean effects and their interactions. Mean separation was used by the least significant differences (L.S.D) methods (Steel and Torrie, 1980).

\section{RESULTS AND DISCUSSION}

Over all results showed significant differences in root number and length for the two examined cutting lengths. However, IBA treatments showed significant differences only in root number (Table, 1). This agrees with (Blavesly \& Chaldecott, 1993) that absolute level of auxin is important for stimulation of the primary events of root initiation. Cuttings length has been previously reported to have strong impact on grapevine rooting potential and survival (Jiang et al 2000 and Harmail et al 1986). Longer cuttings (4-5 nodes) had longer roots $(14.25 \mathrm{~cm})$ and more root number (21.80 roots) than shorter (1-2 nodes) cuttings $(9.75 \mathrm{~cm} \mathrm{\&}$ 10.96 roots) Table 2. Van Elk (1969) indicated that longer stem cutting was the most common cutting length in Holland for woody plant propagation. In a study by Hinesley and Blazich (1984), hardwood stem cutting from hardwood rooted better when cutting length was $24 \mathrm{~cm}$ as opposed to $12 \mathrm{~cm}$. Their work showed that long cuttings produced more and longer roots. In grapevine, the greatest number of roots and longest ones were produced from longer cuttings compared to shorter ones (Harmail et al 1986). However, Iacob \& Popescu, (1977) found that the effect of cutting length varied widely among grapevine varieties. This could be the result of internal factors such as availability of carbohydrates, 
Table 1. Means of root number and root length $(\mathrm{cm})$ of Vitis vinifera var. Maddini stem cuttings as influenced by different cutting length and IBA concentrations

\begin{tabular}{|lcc|}
\hline \multicolumn{1}{|c}{ Treatments } & Root number & Root length \\
\hline Cutting length & & \\
Long cutting & $21.80 \mathrm{a}$ & $14.25 \mathrm{a}$ \\
Short cutting & $10.96 \mathrm{~b}$ & $9.75 \mathrm{~b}$ \\
IBA Levels & & \\
Control & $10.52 \mathrm{c}$ & $10.67 \mathrm{a}$ \\
300 ppm & $15.93 \mathrm{~b}$ & $12.97 \mathrm{a}$ \\
$500 \mathrm{ppm}$ & $22.80 \mathrm{a}$ & $13.72 \mathrm{a}$ \\
$1000 \mathrm{ppm}$ & $16.28 \mathrm{~b}$ & $10.67 \mathrm{a}$ \\
\hline
\end{tabular}

- Means followed by the same within columns letter are not significantly different at $5 \%$ level

nitrogen, auxin and rooting co-factors (Salisbury \& Ross, 1987).

Increasing IBA concentration up to $500 \mathrm{ppm}$ led to the highest root number (22.80 roots). The 1000 ppm IBA treatment showed fewer root number $(16.28$ roots) and was statistically similar to the $300 \mathrm{ppm}$ treatment (15.93 roots) (Table 1 \& Fig. 1). Although the increases in root length which were detected, IBA has been reported to induce higher root number when applied to grapevine cuttings (Patil et al 2000; Cristoferi et al 1988; Tewari, 1986 and Shatat, 1986). Ehrlinger \& Howell (1981) reported different rooting responses with IBA levels when propagating different grape cultivars. In another study the effect of IBA treatment on rooting of grape stem cuttings was influenced by the different collection date of grape cuttings (Goode $\boldsymbol{\&}$ Lane, 1983).

\section{CONCLUSION}

Cutting length (long vs short) showed strong impact on the rooting ability of Vitis vinifera var. maddini. Treating grapevine plant cutting base with IBA showed significant increase in root number, but does not have an impact on root length. These findings will help to establish an effective mass production technique to vegetatively propagation of this valuable commercially important vine at Al-Maddina Al-Monwarah Saudi Arabia.

\section{ACKNOWLEDGMENT}

Special thanks are extended to $\mathrm{Mr}$. Hameed Al-Ayobee, the general manager of the Saudi Arabian Ministry of Agriculture experimental Station at Al-Maddina Al-Monwarah region for providing the Vitis vinifera var. maddini cuttings and the historical and statistical information. 


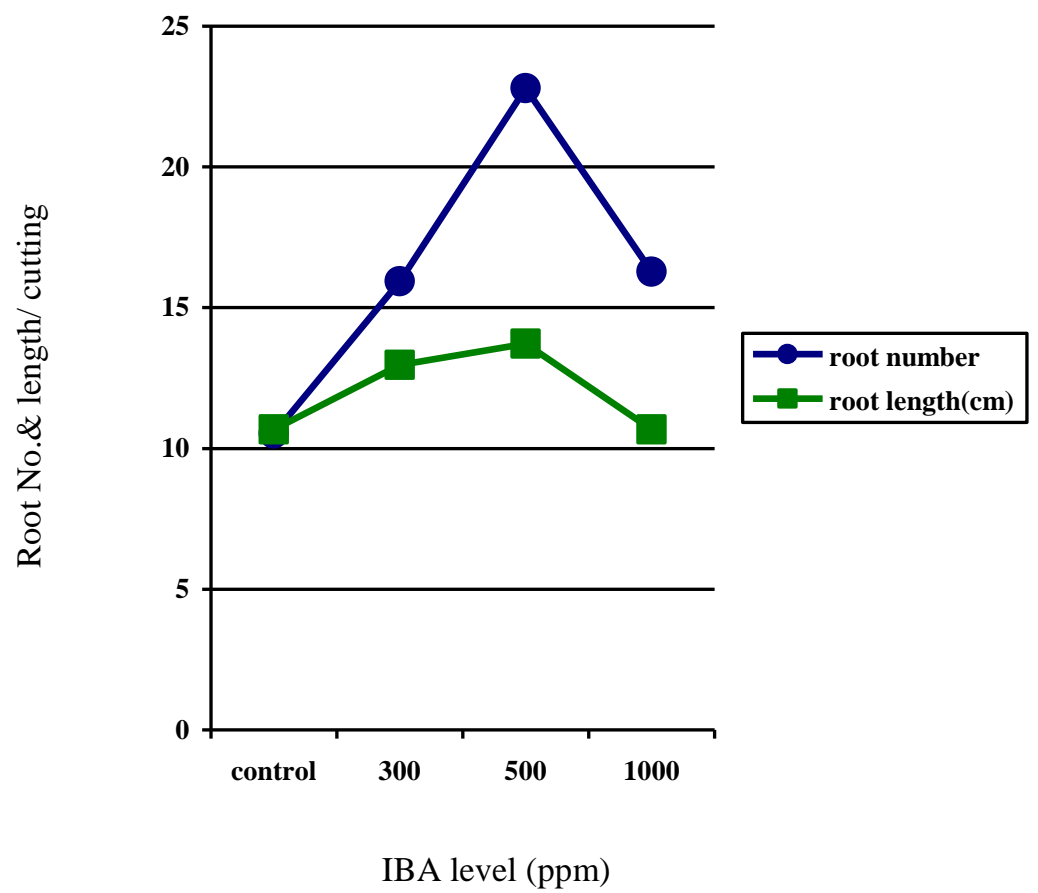

Fig. 1. Means of root number and length $(\mathrm{cm})$ of Vitis vinifera var. maddini stem cuttings as influenced by the different IBA levels.

\section{REFERENCES}

Blavesly, D. and M.C. Chaldecott (1993) The role of endogenous auxin in root initiation. Plant Gro. Reg. 10: 341349.

Castro, P.E.; F. Melotto; I. Soares and C. Pommer (1994). Rooting stimulation in muscadine grape cuttings. Scientia Agric. 3: 436-440.

Cristoferi, G.; N. Filiti, and F. Rossi (1988). The effect of reversed polarity and acropetal centrifugation on the rooting of hardwood cuttings of grapevine rootstock Kober 5BB. Acta. Hort. 227: 150-154.

Ehrlinger, D. and G. Howell, (1981). Differential rooting of hardwood cuttings from different grape cultivars. Plant Propagator 27: 13-15.

Ezzili, B. and M. Bejaoui, (2001). New contribution to the survey of the acrotony theory on the branch of one year grapevine. III: role of buds and leaves in the development, application in the vineyard of results obtained in laboratory and greenhouse. J. of Inter. Scie. Vigen. 35:1-21. 
Fielding, J.M. (1968). Trees grown from cuttings compared with trees grown from seed (Pinus radiate D. Don). For. Res. 20: 116-121.

Geny, L.; N. Ollat and J. Soyer, (1998). Grapevine fruiting cuttings: validation of an experimental system to study grapevine physiology. II. Study of grape development. J. International Sci. Vigne. 32: 83-91.

Goode, D. and R. Lane, (1983). Rooting of leafy muscadine grape cuttings. HortScience 18: 994-946.

Harmail, S.; H. Kumar; P.K. Monga and H. Singh (1986). Effect of cane type and IBA treatments on the rooting of grape cuttings. Indian J. of Hort. 43: 227-229.

Hinesley, L. and F. Blazich, (1984). Rooting Fraser fir stem cuttings. J. Enviro. Hort. 2: 23-26.

Iacob, M. and G. Popescu, (1977). Rapid multiplication of grape by cuttings in nutritive medium. Produc. Veget. Horti. 26: 35-38.

Jiang, C.; H. Sun; D. Shen and C. Jiang (2000). Test of wine grape propagation with single-eyed wood cuttings planted in nutritional bags. J. of Agri. \& Fores. Sci. \& Techn. 1: 15-16.

Kawecki. Z. and W. Kozlowski, (1995) Effect of different organic substrates on rooting of one bud hardwood grapevine cuttings. Acta Academic Agri. Tech. 60: 99-106.

Patil, V.N.; P.S. Chauhan; R.S. Shivankar and R.T. Raghuvanshi, (2000). Effect of growth regulators on rooting of cuttings in two commercial varieties of grape (Vitis vinifera L.). Research on Crops 3: 367-372.

Preece, J.E. (1987). Treatment of the stock plant with plant growth regulators to improve propagation success. HortScience 22: 754-759.

Salisbury, F. and C. Ross, (1987). Plant Physiology 422 pp. Wadsworth Publishing Co. Inc. Belmont, California, USA.

Shatat, F. (1986). Effect of cane type and IBA treatments on the rooting of grape cuttings. Dirasat 13:19-27.

Song, Y.; J. Lu; Y. Wang; Z. Shen, W. Liu and G. Song (2001). Study in the promoting the rooting ability of hardwood cuttings of Amerien grape varieties. China Fruits 1: 4-7.

Steel, R.G.D. and J.H. Torrie, (1980) Principles and Procedures of Statistics, Mc \& Graw-Hill, New York.

Tewari, J.P. (1986). Effect of some plant growth regulators on the rooting and survival of grape (Vitis vinifera L.). Progressive Hort. 18: 48-50.

Thomas, P. and J. Schiefelbein, (2001). combained in vitro propagation for rapid multiplication of grapevine cv. Arak Neelamani. HortScience 36: 1107-1110.

Van Elk, B. (1969). The propagation of conifer by cuttings. Proc. Inter. Plant Prop. Soc. 19: 232-241.

Zhang, P.; D. Xiang; J. Lu; M. Guo; X. Wu and Y. Qi, (1997). Effects of plant growth regulators on the cutting rooting of Fenghuang 51 grape variety. China Fruits 1: 28-29. 
بحلة اتحاد الجامعات العربية للدراسات والبحوث الزراعية ، جامعة عين شمس ، القاهرة ، 13(2) ، 453 - 458 ، 2005

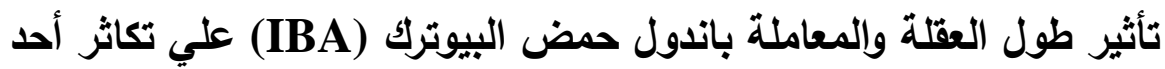
أصناف العنب المحلي في المملكة العربية السعودية

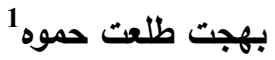

1- قسم زراعة المناطق الجافة - كلية الأرصاد والبيئة وزراعة المناطق الجافة - جامعة الملك عبد العزيز-

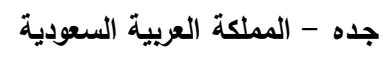

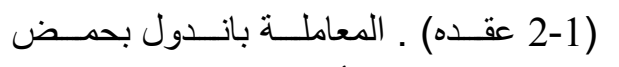

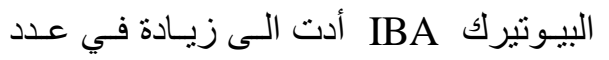
الجذور المتكونـة حتى تركيز 500 جزء في في المليون ، ولكن لم تظهر نتائج معنوية بالنسبة

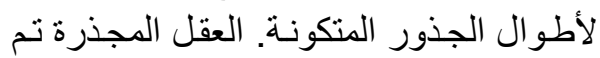

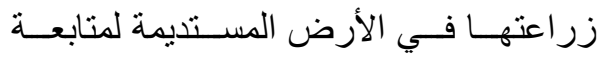
نمو ها. نتائج هذه الدر اسـة قد تسـاهم في رفـع

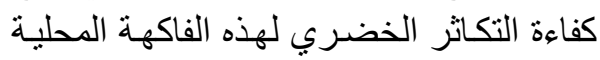

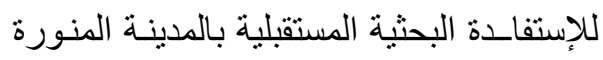

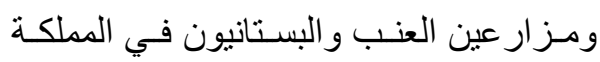

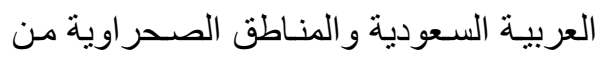

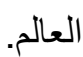

وجـد مـن خـلال الدر اسـة التـي قـام بهـا

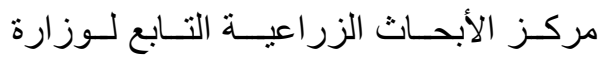

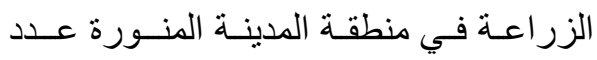
قليـل من بساتين العنب ذات الإنتاجيـة العاليـة

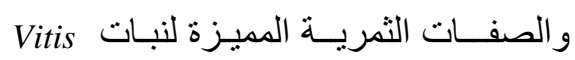
vinifera var. maddini

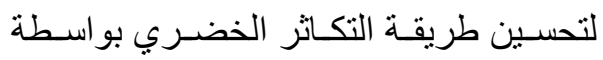
تجذير العقل الساقية وذلك من خلال التركيز

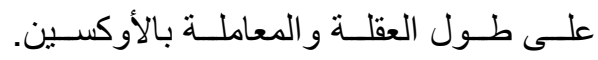

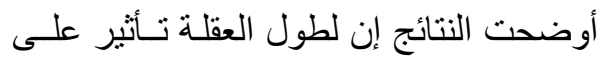
التجذير ، و العقل الطويلة (4-5 عقده) تميزت

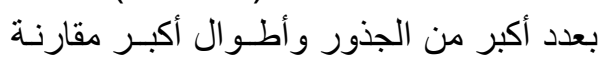

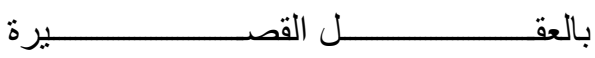

تحكيم: أ.د محمد أبو رواش على بدر

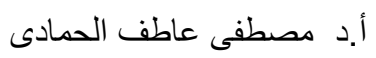

